\title{
International Berkeley Society Conference "Berkeley's Philosophy after the Principles and the Three Dialogues" - Institute of Philosophy, Nicolaus Copernicus University, Toruń, Poland, 23-26 October 2017
}

DOI: http://dx.doi.org/10.12775/RF.2018.043

The tradition of the studies on the history of modern philosophy, especially German and British, at the Institute of Philosophy, Nicolaus Copernicus University, was the reason for holding an international conference "Berkeley's Philosophy after the Principles and the Three Dialogues" on 23-26 October 2017. The meeting under the auspices of International Berkeley Society and Torun Division of Polish Philosophical Association was organized by Bertil Belfrage (Lund University) and Adam Grzeliński (Nicolaus Copernicus University, Toruń). The conference was one of the annual meetings organized by IBS in various scientific centres (recent conferences were held in Kraków (2013), Dublin (2014), Jerusalem (2016), Galway (2017), and Newport (2018)). The Torun event also crowned the research carried out at the Institute of Philosophy which involved the preparation of the first Polish translations of several works and writings by Berkeley as well as the organisation of three Torun Berkeley Workshops with Bertil Belfrage, Laurent Jaffro, and Roomet Jakapi as keynote speakers.

The issues discussed by Berkeley in his works published after the Principles and the Three Dialogues were the leading theme of the conference. For obvious reasons, the contributions referred not only to a wide range of topics found in De motu, Alciphron, Siris, and The Querist but also to the whole philosophical output of the bishop and the existing editions of his works.

Opening the conference, Bertil Belfrage focused on the shortcomings of the Luce-Jessop edition of Berkeley's works pointing at the necessity to differentiate between presenting a text (which is the editor or historian's task) and exposing, analysing and supporting particular aspects of this text (which is the philosopher's task). The bias of their edition resulted from losing the balance between these two tasks. Another criticism concerning the way the writings by the Irish philosopher had been 
edited was raised by John Blechl who undermined the traditional division between the "major" works, significant from the philosophical perspective, and the "minor" writings, which are usually neglected while investigating the interpretation of Berkeleyanism; the distinction leads to various misunderstandings resulting from fragmentary and selective treatment given to the philosopher's writings.

The richness of Berkeley's philosophical output in the later period, not confined to explication of the immaterialist thesis and epistemological issues, created an opportunity for several scholars to make their contribution to general topics which seldom draw the researchers' attention. Tom Stoneham pointed out the change of accents in Berkeley's thought in the 1720's: though still opposing free-thinkers, he shifted from an attack on materialism as the ultimate philosophical source of the doctrine to the direct promotion of education and moral improvement as a means of undermining its seductive effects. Berkeley's engagement in various educational projects can be thus understood in the light of his strictly philosophical views. Another unchangeable feature of Berkeley's philosophy was indicated by Silvia Parigi for whom the earlier and later works, though developing various problems, can be reconciled as belonging to the general project of Christian enlightenment. Perceived from such a perspective, the enlightenment was not limited to free-thinking and irreligiousness, and the combination of religious and progressive motifs can cast some interesting light on the unity and coherence of Berkeley's philosophy. Also for Paweł Hanczewski Berkeley's writings send their readers to the wide context of the philosopher's times since a certain range of texts deals with the issue of the Irish nation identity. Problems raised in works such as An Essay Towards Preventing the Ruin of Great Britain, Alciphron, The Querist and several minor writings contained Berkeley's responses to the political, social, and economic situation of his country. His efforts to solve those problems can thus be inscribed within the process of gaining identity by Ireland in the $18^{\text {th }}$ century.

Three of the papers put Berkeley's thought in a historic-philosophical contexts. Stephen H. Daniel offered a reconstruction of Cartesian and Lockean threads in Berkeley's philosophy which start with De Motu (1721) and which unite more practical aspects of his later philosophy with theoretical ones found in the earlier. Kenneth L. Pearce, in turn, focused on the impact Thomas Hobbes had on Berkeley. Such an interpretation stands in contradiction to typical reading according to which Berkeley, an Anglican clergy member, was in a sharp opposition to the infidel "monster of Malmesbury". Another context was indicated by Manuel Fasko who analysed the interpretation of Cardinal Cajetan's understanding of divine analogy presented by Berkeley in the fourth dialogue of Alciphron; although the Irish philosopher was familiar with De Nominum Analogia by Cajetan, he favoured the literal understanding 
of divine predication quite different than the notion of proper proportional analogy used in Cajetan's work.

Also two other academics delivered their papers relating to Alciphron. Artem Besedin emphasized the importance of Berkeley's position regarding free will in the work and indicated it had stemmed from the discussion between Samuel Clarke and Anthony Collins. According to his interpretation, Berkeley's libertarianism concerning free will can be reconciled with his compatibilist position regarding accountability. Another question was discussed by Peter West who talked on the interdependence of anti-abstractionist account of ideas and the theory of meaning presented in the seventh dialogue of the work; this correlation seems to be the evidence for the fact that Berkeley held a non-ideational theory of meaning from his early Manuscript Introduction to Alciphron and explains the deletion of certain parts of the latter work in the 1752 edition.

Two other works analyzed during the conference were De Motu and Siris. Richard Brook juxtaposed the scientific explanation of natural phenomena offered in the former work with Berkeley's own interpretation according to which his approach to the philosophy of nature is similar to that of Newton. However, the sharp distinction between metaphysics (in which casual explanation is possible) and science (in which no efficient causality can be spoken of) challenges the view and makes the academic look at contemporary theories developing deductive-nomological explanation as a possible interpretation of Berkeley's stance. A similar topic was raised by Ville Paukkonen who claimed that, together with the New Theory of Vision, De Motu is the text in which Berkeley develops his theory of volitional causality in detail. The interpretation of the texts falls within the recent debate concerning the occasionalist and concurrentist understanding of the agent causation. Another analysis of De Motu was made by Takaharu Oda who focused on the relation between the "real", i.e. efficient and volitional, causality and the natural causality referred to by natural sciences. As can be read in the article resulting from his conference paper, volitional causation regarding bodily motion can be offered an alternative, conservationist interpretation, different than the occassionalist one.

In his paper on the metaphysics of light and the spirit of nature, Dariusz Kucharski revealed striking similarities between Siris and the works by Henry More. Though no evidence of any direct influence between the two thinkers can be found, the similarity of their metaphysics seems to be caused by the Neoplatonic elements in their philosophies and certain theological issues both thinkers addressed (the problem of God's presence and activity in the natural world and the struggle of natural philosophers to avoid pantheism and atheism). As David Bartha pointed out in his presentation, though quite unique in Berkeley's philosophical output due to the Neoplatonic metaphysical framework, Siris provides 
a voluntarist understanding of the laws of nature even more explicitly than his earlier works. The voluntarist interpretation reveals the fact that immaterialism is not necessarily presupposed in the argumentation given in Siris. A similar view was the main motif in the paper presented by Adam Grzeliński in which the stress was put on the irrelevance of the materialism-immaterialism controversy over understanding the late work by Berkeley. Though it includes the development of the notion of spirituality, such understanding of nature can be reconciled with corpuscular theories referred to by the author of Siris.

The articles published in this issue of "Ruch Filozoficzny Quarterly" are either extended versions of the conference papers or refer to them topically. In the separate section of the issue short reviews of two most recent Polish monographs are presented: Istnienie $i$ umyst. Studium podstaw filozofii George'a Berkeleya [Existence and Mind. A Study of George Berkeley's Philosophical Fundamentals] by Piotr Szałek and W stużbie Bogu iczłowiekowi. Zarys problemu patriotyzmu w myśli George'a Berkeleya [In God's and Man's Service. An Outline of the Issue of Patriotism in George Berkeley's Thought] (2016) by Marta Szymańska-Lewoszewska. Up to some degree, they supplement previously published information on Berkeley scholarship carried out in Poland (M. Szymańska-Lewoszewska, "George Berkeley's Philosophy in Polish Studies," Berkeley Studies 19 (2008)).

\section{The full conference programme:}

Bertil Belfrage (Lund University), “The Unknown Berkeley: Consequences of a Biased Edition"

Dariusz Kucharski (Cardinal Stefan Wyszyński University), "Spirit of Nature and Metaphysics of Light. Some Sources for Siris"

Adam Grzeliński (Nicolaus Copernicus University), "The Irrelevance of the Immaterialist Thesis in Berkeley's Siris"

Richard Brook (Bloomsburg University), "Berkeley, Newton, Explanation, and Causality"

Ville Paukkonen (Boğaziçi University), "Berkeley's Theory of Agent Causation: Finite and Infinite Agents and the Question of Necessary Connections"

David Bartha (Central European University), "Laws of Nature and the Divine Will in the Siris"

Peter West (Trinity College Dublin), "Anti-Abstractionism and Berkeley's Theory of Meaning in Alciphron 7"

Takaharu Oda (Tartu University), "Berkeley's Metaphysics of Causality in De Motu"

Stephen Daniel (Texas A\&M University), "Berkeley on Descartes and Locke after $1720^{\prime \prime}$ 
Kenneth L. Pearce (Trinity College Dublin), "The Monster of Malmesbury and the Bishop of Cloyne: Hobbist Origins of Berkeley's Theory of Meaning and Inference"

Silvia Parigi (Istituto Italiano per gli Studi Filosofici), “Berkeley's Christian Enlightenment"

Pawel Hanczewski (Nicolaus Copernicus University), “George Berkeley: Forging the Irish Nation"

Tom Stoneham (University of York), “Deliverance from Error: Berkeley on Education and Moral Improvement"

Artem Besedin (Moscow State University), "Berkeley on Free Will and Accountability in Alciphron VII"

John Blechl (University of York), "The 'Minor Publications Hypothesis"”

Manuel Fasko (University of Zurich), "Berkeley's Cajetan or Alciphron IV $\S 21$ Revisited"

Adam Grzeliński

Nicolaus Copernicus University, Toruń

ORCID: 0000-0002-4007-6507

e-mail: Adam.Grzelinski@umk.pl 